\title{
Some aspects of modern vision for geoenergy usage
}

\author{
Roman Dychkovskyi ${ }^{1 *}$, Mykola Tabachenko ${ }^{1}$, Kseniia Zhadiaieva ${ }^{1}$, and Edgar Cabana ${ }^{2}$ \\ ${ }^{1}$ Dnipro University of Technology, Department of Underground Mining, 19 Yavornytskoho Ave., \\ 49005 Dnipro, Ukraine \\ ${ }^{2}$ Universidad Nacional de San Agustin de Arequipa, Institute of Renewable Energy Research and \\ Energy Efficiency, 107 San Agustin Str., 04000 Arequipa, Peru
}

\begin{abstract}
The paper represents analysis, which have helped to determine tendencies of usage secondary and renewable resources by means of their utilization within the closed ecological complex while implementing integrated cogeneration systems belonging to various sources. Both the current state and prospects of secondary and renewable resources use within the closed complex of a mining enterprise have been considered. Relying upon philosophical approaches as for the formation of a viewpoint concerning responsibility of the modern society to future generations, tendencies to form energy production and energy consumption on the basis of alternative radical technologies have been proposed. The authors have put forward tendencies to change coal mining and coal use while generating the raw material from the abandoned and out-of-balance reserves. Chances to use cogeneration systems by various energy sources have been considered. Formation of the unified power and chemical system to improve economic and ecologic expediency of the proposed measures is the key tendency of energy perfection as well as minimization of impact on the underground mine environment and on the surface to prolong activities of dying mining territories and to reduce social tension.
\end{abstract}

\section{Introduction}

Currently, our society is at the stage of a new technological period, 4.0 Industry. Its implementation leads to the necessity to form new principles of all types of social relations $[1,2]$. Its current implementation is followed by a dynamic increase in energy consumption and by formation of challenges which may endanger human civilization [3-5]. It should be noted that such an outcome may result from the deficiency in human power supply rather than from military conflicts or global ecological disasters $[6,7]$.

The problem understanding must change our mentality and formulate comprehension of responsibility to future generation as for conservation of natural resources and common values of mankind; the necessity to form new philosophical ideas and currents which will unite separate multinational groups of people. They should explain the problem complexity;

\footnotetext{
* Corresponding author: dychkovskyi.r.o@,nmu.one
} 
introduce light and openness into educational processes at high schools and at universities.

Nowadays, we should have education program which would shape environmentally friendly public opinion of responsibility, mutual understanding, and tolerance. The problem is topical for so-called emerging economies. It is the purpose in behalf of which we have formed the international writing staff, engaged in solving problems to form cogeneration systems with the help of innovative approaches, and philosophers, who can evaluate socalled humanitarian challenges of a society resulting from the implementation of the obtained results of technological upgrading. The authors have represented their findings in proper papers $[8-10]$. The papers were released in the Ukrainian language by the specialized Ukrainian publications. We believe they should be represented to a wider scientific community. Thus, the obtained results were generalized and completed by us and we submit them for general discussion.

Along with the intensified use of fossil nonrenewable energy sources, ecologic tension is increasing in mining regions $[11,12]$. Such a situation has been observed in our fuel and energy complex of our country, and in countries of Latin America which energy sector is oriented to the use of primary nonrenewable energy resources (i.e. natural gas, crude oil, coal, and uranium) [13-15]. It is known for a fact that right coal and uranium will remain the basic fuel and energy resources for the majority of the mentioned countries in the near future.

Hence, on the one hand, it is necessary to work for maximum implementation of the closed cycle of stock preparation for NPSs $[16,17]$; on the other hand, it is required to stabilize coal extraction and consumption [18-20]. That is stipulated by the limited reserves of crude oil and natural gas, forming negative tendencies in the world market, and by the unsolved problems concerning absolute safety of nuclear power stations, and reliable disposal of neutralization of radioactive residues of nuclear fuel [21, 22].

At the same time, traditional methods of coal extraction and consumption stipulate transformation of coal-mining regions into zones of ecological disaster [23, 24]. Analysis of state of Ukrainian coal-burning enterprises demonstrates numerous values of waste production. Annually, each $\mathrm{kW}$ of total capacity of a coal thermal power plant (TPP) discharges $450-500 \mathrm{~kg}$ of ash and slag, $10-15 \mathrm{~kg}$ of nitric oxides, and $70-80 \mathrm{~kg}$ of Sulphur oxides. Annually, electric power stations with $180-250 \mathrm{~mW}$ capacity discharge $80-120$ thousand tons of solid particles, $1.5-2.5$ thousand tons of nitric oxides, and $10-$ 20 thousand tons of sulfides [8].

Despite the declared replacement of traditional power industry for alternative renewable sources, forecasts for the near decades show almost $25-35 \%$ increase in thermal energy and electrical energy generation $[25,26]$. In the context of the available system for waste utilization, discharge of harmful substances will be enormous resulting in ecologic cataclysms.

\section{Geoenergy innovative technologies development}

Essence of modern technologies for geo-power management of underground and terrestrial resource environment are several inevitable components, on the basis of which principles of the mineral and energy raw materials usage should be formed [27, 28]. First and foremost, this is the maximum removal of all components of mining production at an economically feasible level and ensuring the environmental impact of the environment $[29,30]$. It is also necessary to provide for the use of all aggregate empty rocks released to the surface as a result of mining activities, the restoration of atmospheric and water balance and solving other relevant problems [31-33]. A lot of attention is given to the question of the formation of the complexity of extraction and processing of minerals, as well as the extraction of reserves in complicated mining and geological conditions [34-36]. Let's 
consider the directions of innovation technological improvement according to the most accessible sources in our countries and developed innovative technological solutions.

\subsection{Coal power sector}

To our opinion the coal together with the uranium as raw materials will remain a guarantor of energy independence of Ukraine for the nearest decades [37]. Currently, there are thee tendencies to widen the use of coal as a primary energy carrier:

- deep coal excavation from bunks of wastes. It means that the dumps contain a sufficient amount of useful combustible components, which turns them into deposits of technogenic origin;

- coal burning by so called TPPs with the necessity to catch solid and gaseous harmful substances. Operation of such coal-burning devices is rather expensive which results in the increased prime cost of a $\mathrm{kW}$ of energy;

- transformation of coal immediately within the areas of its occurrence into eco-friendly gaseous energy.

\subsection{Alternative coal power sector}

The scientists of the Dnipro University of Technology have developed innovative and ecofriendly complex cogeneration system to obtain artificial energy carriers and chemical substances on the basis of underground well coal gasification (UWCG). The engineering solutions involve the varied approach to the environment as well as production waste control. Criteria to evaluate such solutions are to avoid waste production instead of waste neutralization (as it is done today) [38, 39].

UWCG is one of the manless coal mining methods. Moreover, it is implemented by means of hard fuel transformation into gaseous energy carrier right in place. Using compressors, blow mixture is fed into a coal seam through the drilled wells; gas, formed as a result of gasification and coal decomposition, is delivered to the surface through another group of wells. After purification, it is transported to consumers.

The method is of a great social importance since staff will be free of heavy underground work while being followed by significant power, ecologic, and economic advantages to compare with traditional methods of coal mining. In the context of the problem, being considered, following combinations of complex enterprises are the most attractive: WGPE - production of power generator gas and technologic generator gas; WGPE - gas turbine to generate electricity; WGPE - production of biogas which then is mixed with generator gas to increase its energy value; WGPE - chemical complex to produce chemical substances; WGPE - utilization complex to transform thermal energy of waste gas (hot water and air obtaining; increase of kinetic energy in high towers to transform rate of warm air motion into electric energy with the help of wind plants; utilization of thermal energy of smoke emissions of a gas turbine, compressor facilities etc.).

\subsection{Heat pump generation}

Another important tendency for geoenergetics can be proposed to Ukraine, i.e. heat pump generation on the basis of low-temperature energy sources [9].

The following may become heat sources for a thermal pump:

- thermal energy of waste gases in the process of coal gasification;

- water (underground water, near-surface water, ground water, surface water etc.);

- technogenic water (cooling water, discharge water, and industrial waste);

- geothermal energy (ground energy, rock energy, and near-volcano thermal energy); 
- technogenic waste gases (secondary power resources);

- air (outside air, ventilation air);

- solar radiation;

- utilization of heat of secondary and renewable power resources.

However, if use of heat pump generation extends to public sphere, problems arise connected with the heat use during summer when its demand decreases significantly. One of the ways to solve the problem is seasonal (i.e. during 180 summer days) heat accumulation for its further use during a heating period. Thus, it becomes possible to implement following technological chain: cogeneration plant - rock accumulator or ground accumulator - extraction system on the basis of heat pump plant (HP plant).

\subsection{Wind energy sector}

It is proposed to mount wind plants, united in the integrated system, in the available mine workings [40]. Wheels of the plants move at the expense of surface-underground pressure difference. Air movement is stable within mine workings, and velocity of air masses travel is constant. Hence, wind power may be the rather efficient in mines to be closed down. Moreover, development of high wind turbines, and construction of wind power plants (WPPs) with up to $1000 \mathrm{MW}$ capacity is under consideration. Diameter of the wind wheels will achieve $115-140 \mathrm{~m}$. It is planned to construct such electric power stations in highlands and in coastal areas.

Surface wind energy use is promising tendency as well. However, variability of air flow motion is the key problem preventing from wide application of the surface wind power plants. The WPPs operate on the open space with low efficiency due to constant and frequently varied stream of air flow resulting from random uncontrolled natural processes.

\subsection{Combined power systems}

Currently, new systems of the combined (cogenerative) production of electrical energy, thermal energy, and mechanical energy become more and more popular in the industrialized countries. In Ukraine, cogeneration method to produce energy carriers using one source, i.e. gas of the well coal gasification with the use of free piston plants and thermal energy accumulators, is the most attractive [42]. A group of free piston plants (FPPs) operates on generator gas actuating electric generators. Leaving FPPs, hot gases get waste-heat boiler where steam is generated. Then the steam is directed to a steam-water system where secondary thermal and electric energy are generated. Two thermal accumulators use heat of the waste gases from the waste-heat boiler: one - in autonomous peak contour generating third electric energy, and another one - in underground geotechnological accumulator to utilize heat and use it for heating.

Advantages of the combined power system are as follows: simultaneous extraction of gaseous energy carrier from coal and its use to generate electrical energy, mechanical energy, and thermal energy; ash and rock interlayers, being coal components, remain in the mined-out area during gasification; maneuverability of a cogeneration power system increases at the expense of the use of two isothermic battery tanks with transitory liquid and solid thermal carriers; electrical energy and thermal energy are generated in terms of secondary mode and third mode (inclusive of a peak one) which improves significantly electric power supply reliability; and conditions are created to return waste gases from the traditional power production $\left(\mathrm{CO}_{2}, \mathrm{NO}_{\mathrm{x}}\right.$, and $\left.\mathrm{SO}_{\mathrm{x}}\right)$ again to the underground gasification zone where $\mathrm{CO}_{2}$ transforms into $\mathrm{CO}$, being a combustible gas, and $\mathrm{NOx}$ and $\mathrm{SO}_{\mathrm{x}}$ oxides becomes nontoxic which influences positively neutralization of green-house effect and acid rains. The current situation in the energy services market and the opportunities provided by 
modern energy generation technologies provide opportunities for virtually complete processing of all raw materials, which were raised to the surface. Moreover, it concerns both components used for the direct purpose of power generation and "empty" wallrocks. Another element is the processing of available, issued to the surface of waste mining products. They also need to be processed using cogeneration technologies and returned to productive cycle.

Certain features of the use of cogeneration technologies should be mentioned. First, electric energy is generated practically where it is consumed. That helps avoid huge losses (up to $15-18 \%$ ) within the electric power transmission lines. Such an approach makes it possible to provide residential areas or enterprises, serviced by correspondent boiler houses, with own energy almost in full. Exclusive of power enterprises, it will help solve local power problems or even regional ones. Second, fuel combustion in cogeneration tank results in the significant decrease of harmful emission to compare with separate combustion of the same amount of similar fuel.

Cogeneration plants will help save almost 10-12 million tons of equivalent fuel annually. Ukraine has real possibility to implement the idea since the majority of thermal power stations will deplete their boundary resources in the near future. According the Peru, these possibilities where not yet established.

\subsection{Thermal energy sector}

Earth's heat is the only power resource of future which development helps cheapen useful energy to compare with the traditional fuel thermal power [9]. Taking into consideration further nature study as well as geothermal energy resources, effective technology of its extraction from subsoil will be developed. The technology will provide actually wide use of deep heat. Geothermal resources are connected with dynamic carriers of subsoil thermal energy (i.e. steam-water mixtures, steam, and water) and with those being actually waterless (i.e. water-impermeable) heated rocks. Resources of type one are hydrothermal resources; resources of type two are petrothermal ones.

Thermal water at 50-800 temperatures is distributed over Ukraine (the Carpathians, Crimea, and other regions). There are several techniques helping bring deep heat to the surface: drilling wells to let steam-water mixture discharge; cold water injecting into one of the wells to obtain hot water either through another well or through a group of wells; using natural sources; and using heat-transfer devices mounted within a well head.

Currently, geothermal energy can be applied together with heat pump plants. They may use heat by natural renewable energy sources to generate high-potential heat to be utilized successfully in housing and municipal sector of economy consuming much expensive and insufficient organic fuel. Development of energy-saving technologies should involve complex possibilities of several environmentally friendly energy sources involving sun, rock, soil, and geothermal energy basing upon a heat pump cycle.

\section{Development the artificial energy carriers, and chemical substances using coal}

A number of operation schedules to recycle different origin waste and products of synthesis gas conversion $\left(\mathrm{CO}+\mathrm{H}_{2}\right)$ are known [43, 44]. High cost is their key disadvantage. However, use of the mentioned relatively cheap UWCG method will justify the efforts made to develop efficient technologies intended to obtain artificial energy carriers and chemical substances [45-47]. In addition to the fact that the organic synthesis technology makes coal acceptable for the production of synthetic motor fuels (i.e. gasoline or methanol), it also refines the finished products of fuel processing and combusting as for the 
content of sulphide and other additives as well as substitutes of natural gas, hydrogen, resins, polymers, fertilizers, feed proteins, and other chemical substances [48].

The potential to produce artificial energy carriers and chemical substances, using coal, leads against more extensive question on the importance of synthetic substitutes while solving problems of control of gradual depletion of traditional mineral resources [49-52]. In terms of their content and tendency, the engineering solutions correspond to the requirements of ecological efficiency of the combined thermochemical processes as well as a degree of anthropogenic transformation of natural regional ecosystem. It is also important to evaluate qualitative state of the environmental parameters.

Hence, while solving social problems, coal seam gasification may become ecological aid-man for negative consequences of the current fuel and energy complex. It is planned to liquidate solid waste by means of the degassed area backfilling (mine rocks, overburden rocks, ash, flotation tailings of coal preparation, solid and toxic urban waste, waste of metallurgical and coke-chemical works etc. are meant) using hardening backfill technic [53].

In turn, the process will help preserve landscape within the degassing area [54-56] while returning alienated land to agricultural enterprises without its recultivation. Moreover, it will also help convert smoke emissions $\left(\mathrm{CO}_{2}, \mathrm{NO}_{\mathrm{x}}\right.$, and $\left.\mathrm{SO}_{\mathrm{x}}\right)$ into combustion components and nontoxic ones thus decreasing significantly smoke content in the atmosphere, formation of acid rains as well green-house effect (Fig. 1).

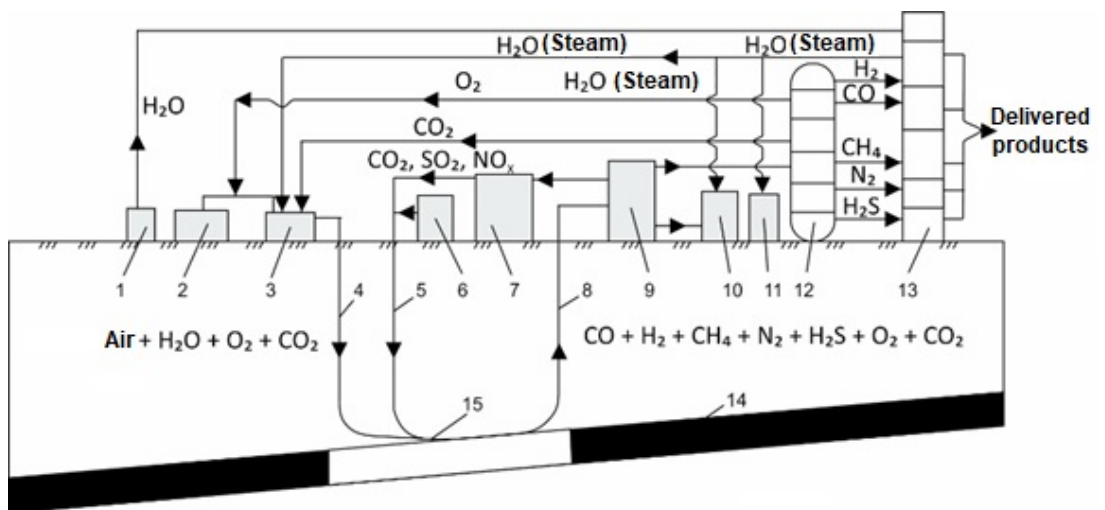

Fig. 1. Scheme of the integrated thermochemical production of artificial energy carriers based upon coal seam gasification: 1 - water supply station; 2 - compressor plant; 3 -blow mixer; 4 -injection oriented well; 5 -well for dust like filling material supply and dusty gas circulation; 6 - pneumatic backfilling complex; 7 -thermal electric power station; 8 - gas-discharge oriented well; 9 - dusttrapping unit; 10 - steam-gas turbine; 11 - steam turbine; 12 - membrane gas separator; 13 - complex for chemical gas processing; 14 - coal seam; 15 - underground gas generator.

Gas generator enterprise may also produce biogas, environmentally friendly fertilizers, electric energy; extensive network of hothouse farms may be developed, and power-andheat supply of settlements may be performed. Energy UWCG gas is the most efficient while using by gas turbines to generate electric energy.

\section{Conclusions}

Despite the development of alternative energetics, energy generation will increase in the near future. That will step up ecologic pressure on mining regions while necessitating the development of new utilization technologies as well as industrial use of the waste. Improvement of the available technologies as well as the development of new ones in the 
field of traditional thermal energetics and nuclear energetics, when there are no emissions of harmful substances, is the promising tendency. Moreover, it is necessary to involve in production the available tailing dumps with their consideration as mineral deposits and energy feedstock of technogenic origin.

Thermochemical energetics may become qualitative jump in the context of production force development which will make it possible to block the forthcoming raw ecological crisis, and turn radically progress of energetics, mining sector, and other industries.

This work contains the researches, which were conducted within the grant No. 0117 U001127 (financed by the Ministry of Education and Science of Ukraine), "VirtualMine: as a Modeling Tool for Wider Society Learning" and Dubrovnik International ESEE Mining School (projects in the frame of EIT Raw Materials).

\section{References}

1. Haiko, H. (2019). The Philosophy of Mining: Historical Aspect and Future Prospect. Philosophy \& Cosmology, (22), 76-90. https://doi.org/10.29202/phil-cosm/22/6

2. Bazaluk, O., \& Blazhevych, T. (2016). The Image of an Ideal Ukrainian Politician. Ukrainian National Idea. Future Human Image, (6), 24-30.

3. Rozin, V.M. (2017). Technology as a Time Challenge: Study, Concept and Types of Technology. Philosophy and Cosmology, (19), 133-142.

4. Beshta, O.S. (2012). Electric drives adjustment for improvement of energy efficiency of technological processes. Naukovyi Visnyk Natsionalnoho Hirnychoho Universytetu, (4), 98-107.

5. Pivnyak, G., Razumny, Y., \& Zaika, V. (2009). The problems of power supply and power saving in the mining industry of Ukraine. Archives of Mining Sciences, 54(1), 5-12.

6. Melnyk, T. (2018). Ukraine and Its Future in a Globalised International Community. Ukrainian Policymaker, (3), 17-28. https://doi.org/10.29202/up/3/3

7. Aitkazinova, S., Soltabaeva, S., Kyrgizbaeva, G., Rysbekov, K., \& Nurpeisova, M. (2016). Methodology of assessment and prediction of critical condition of natural-technical systems. International Multidisciplinary Scientific GeoConference Surveying Geology and Mining Ecology Management, SGEM 2, 3-10. https://doi.org/10.5593/sgem2016/b22/s09.001

8. Pivniak, H.H., Beshta, O.S., Pilov, P.I., Dychkovskyi, R.O., Tabachenko M.M., \& Falshtynskyi, V.I. (2013). Ekonomichni i ekolohichni aspekty kompleksnoi heneratsii ta utylizatsii enerhii v umovakh urbanizovanykh i promyslovykh terytorii. Dnipro: Natsionalnyi hirnychyi universytet.

9. Tabachenko, M.M., Samusia, V.I., Dychkovskyi, R.O., \& Falshtynskyi, V.I. (2012). Novitni pryntsypy teplonasosnykh ta koheneratsiinykh tekhnolohii vykorystannia vykydnoho tepla. Dnipro: Natsionalnyi hirnychyi universytet.

10. Dychkovskyi, R.O. (2015). Determination of the rock subsidence spacing in the well underground coal gasification. Naukovyi Visnyk Natsionalnoho Hirnychoho Universytetu, (6), 30-36.

11. Sarycheva, L. (2003). Using GMDH in ecological and socio-economical monitoring problems. Systems Analysis Modelling Simulation, 43(10), 1409-1414. https://doi.org/10.1080/02329290290024925

12. Petlovanyi, M., Kuzmenko, O., Lozynskyi, V., Popovych, V., Sai, K., \& Saik, P. (2019). Review of man-made mineral formations accumulation and prospects of their developing in mining industrial regions in Ukraine. Mining of Mineral Deposits, 13(1), 24-38. https://doi.org/10.33271/mining13.01.024

13. Cabana, E.C. (2017). Formation of thermal fields by the energy-chemical complex of coal gasification. Naukovyi Visnyk Natsionalnoho Hirnychoho Universytetu, (5), 36-42.

14. Caceres, E., \& Alca, J.J. (2016). Potential For Energy Recovery From A Wastewater Treatment Plant. IEEE Latin America Transactions, 14(7), 3316-3321. https://doi.org/10.1109/tla.2016.7587636 
15. Caceres, E., \& Alca, J.J. (2016). Rural Electrification Using Gasification Technology: Experiences and Perspectives. IEEE Latin America Transactions, 14(7), 3322-3328. https://doi.org/10.1109/TLA.2016.7587637

16. Kalybekov, T., Rysbekov, K.B., Toktarov, A.A., Otarbaev, O.M. (2019). Underground mine planning with regard to preparedness of mineral reserves. Mining Informational and Analytical Bulletin, (5), 34-43.

17. Rysbekov, K., Huayang, D., Kalybekov, T., Sandybekov, M., Idrissov, K., Zhakypbek, Y., Bakhmagambetova, G. (2019). Application features of the surface laser scanning technology when solving the main tasks of surveying support for reclamation. Mining of Mineral Deposits, 13(3), 40-48. https://doi.org/10.33271/mining13.03.040

18. Vagonova, O.G., \& Volosheniuk, V.V. (2012). Mining enterprises' economic strategies as derivatives of nature management in the system of social relations. Naukovyi Visnyk Natsionalnoho Hirnychoho Universytetu, (2), 127-134.

19. Piwniak, G.G., Bondarenko, V.I., Salli, V.I., Pavlenko, I.I., \& Dychkovskiy, R.O. (2007). Limits to economic viability of extraction of thin coal seams in Ukraine. Technical, Technological and Economic Aspects of Thin-Seams Coal Mining International Mining Forum 2007, 129-132. https://doi.org/10.1201/noe0415436700.ch16

20. Pivniak, H.H., Pilov, P.I., Pashkevych, M.S., \& Shashenko, D.O. (2012). Synchro-mining: Civilized solution of problems of mining regions' sustainable operation. Naukovyi Visnyk Natsionalnoho Hirnychoho Universytetu, (3), 131-138.

21. Medunić, G., Mondol, D., Rađenović, A., \& Nazir, S. (2018). Review of the latest research on coal, environment, and clean technologies. Rudarsko Geolosko Naftni Zbornik, 33(3), 13-21. https://doi.org/10.17794/rgn.2018.3.2

22. Nosić, A., Karasalihović Sedlar, D., \& Jukić, L. (2017). Oil and gas futures and options market. Rudarsko Geolosko Naftni Zbornik, 32(4), 45-54. https://doi.org/10.17794/rgn.2017.4.5

23. Pivnyak, G., Dychkovskyi, R., Smirnov, A., \& Cherednichenko, Y. (2013). Some aspects on the software simulation implementation in thin coal seams mining. Energy Efficiency Improvement of Geotechnical Systems, 1-10. https://doi.org/10.1201/b16355-2

24. Gorova, A., Pavlychenko, A., Kulyna, S., \& Shkremetko, O. (2012). Ecological problems of postindustrial mining areas. Geomechanical Processes During Underground Mining - Proceedings of the School of Underground Mining, 35-40. https://doi.org/10.1201/b13157-7

25. Bondarenko, V. (2015). An overview and prospectives of practical application of the biomass gasification technology in Ukraine. New Developments in Mining Engineering 2015: Theoretical and Practical Solutions of Mineral Resources Mining, 27-32. https://doi.org/10.1201/b19901-6

26. Sai, K., Malanchuk, Z., Petlovanyi, M., Saik, P., \& Lozynskyi, V. (2019). Research of Thermodynamic Conditions for Gas Hydrates Formation from Methane in the Coal Mines. Solid State Phenomena, (291), 155-172. https://doi.org/10.4028/www.scientific.net/SSP.291.155

27. Naduty, V., Malanchuk, Z., Malanchuk, E., Korniyenko, V. (2015). Modeling of vibro screening at fine classification of metallic basalt. New Developments in Mining Engineering 2015: Theoretical and Practical Solutions of Mineral Resources Mining, 441-444. https://doi.org/10.1201/b19901-77

28. Malanchuk, Y., Moshynskyi, V., Korniienko, V., \& Malanchuk, Z. (2018). Modeling the process of hydromechanical amber extraction. E3S Web of Conferences, (60), 00005. https://doi.org/10.1051/e3sconf/20186000005

29. Gorova, A., Pavlychenko, A., Borysovs'ka, O., \& Krups'ka, L. (2013). The development of methodology for assessment of environmental risk degree in mining regions. Annual ScientificTechnical Collection - Mining of Mineral Deposits 2013, 207-209. https://doi.org/10.1201/b16354-38

30. Khomenko, O., Kononenko, M., \& Myronova, I. (2013). Blasting works technology to decrease an emission of harmful matters into the mine atmosphere. Annual Scientific-Technical CollectionMining of Mineral Deposits 2013, 231-235. https://doi.org/10.1201/b16354-43 
31. Chui, Y.V., Moshynskyi, V.S., Martyniuk, P.M., \& Stepanchenko, O.M. (2018). On conjugation conditions in the filtration problems upon existence of semipermeable inclusions. JP Journal of Heat and Mass Transfer, 15(3), 609-619.

32. Bomba, A., Tkachuk, M., Havryliuk, V., Kyrysha, R., Gerasimov, I., \& Pinchuk, O. (2018). Mathematical modelling of filtration processes in drainage systems using conformal mapping. Journal of Water and Land Development, 39(1), 11-15. https://doi.org/10.2478/jwld-2018-0054

33. Kuzlo, M.T., Moshynskyi, V.S., Martyniuk, P.M. (2018). Mathematical modelling of soil massif's deformations under its drainage. International Journal of Applied Mathematics, 31(6), 751-762.

34. Lozynskyi, V.G., Dychkovskyi, R.O., Falshtynskyi, V.S., Saik, P.B., \& Malanchuk, Ye.Z. (2016). Experimental study of the influence of crossing the disjunctive geological faults on thermal regime of underground gasifier. Naukovyi Visnyk Natsionalnoho Hirnychoho Universytetu, (5), 21-29.

35. Dychkovskyi, R., Vladyko, O., Maltsev, D., \& Cáceres Cabana, E. (2018). Some aspects of the compatibility of mineral mining technologies. Rudarsko Geolosko Naftni Zbornik, 33(4), 73-82. https://doi.org/10.17794/rgn.2018.4.7

36. Lozynskyi, V.H., Dychkovskyi, R.O., Falshtynskyi, V.S., \& Saik, P.B. (2015). Revisiting possibility to cross disjunctive geological faults by underground gasifier. Naukovyi Visnyk Natsionalnoho Hirnychoho Universytetu, (4), 22-28.

37. Pivnyak, G.G., \& Shashenko, O.M. (2015). Innovations and safety for coal mines in Ukraine. Naukovyi Visnyk Natsionalnoho Hirnychoho Universytetu, (6), 118-121.

38. Dychkovskyi, R., Falshtynskyi, V., Ruskykh, V., Cabana, E., \& Kosobokov, O. (2018). A modern vision of simulation modelling in mining and near mining activity. E3S Web of Conferences, (60). https://doi.org/10.1051/e3sconf/20186000014

39. Dychkovskyi, R.O. (2015). Forming the bilayer artificially shell of georeactor in underground coal gasification. Naukovyi Visnyk Natsionalnoho Hirnychoho Universytetu, (5), 37-42.

40. Cabana, E. (2018). A concept to use energy of air flows of technogenic area of mining enterprises. E3S Web of Conferences, (60), 00004. https://doi.org/10.1051/e3sconf/20186000004

41. Vagonova, O., Mormul, T., Zakharchenko, Yu., Romaniuk, N., \& Kasianenko, L. (2018). Topical problems concerning both methods and economy to develop mineral deposits. Mining of Mineral Deposits, 12(4), 82-89. https://doi.org/10.15407/mining12.04.082

42. Tabachenko, M., Saik, P., Lozynskyi, V., Falshtynskyi, V., \& Dychkovskyi, R. (2016). Features of setting up a complex, combined and zero-waste gasifier plant. Mining of Mineral Deposits, 10(3), 37-45. http://dx.doi.org/10.15407/mining10.03.037

43. Basu, R. (2017). Evaluation of some renewable energy technologies. Mining of Mineral Deposits, 11(4), 29-37. https://doi.org/10.15407/mining11.04.029

44. Bondarenko, V., Tabachenko, M., \& Wachowicz, J. (2010). Possibility of production complex of sufficient gasses in Ukraine. New Techniques and Technologies in Mining - Proceedings of the School of Underground Mining, 113-119.

45. Sobolev, V. V., \& Usherenko, S. M. (2006). Shock-wave initiation of nuclear transmutation of chemical elements. Journal de Physique IV (Proceedings), 134, 977-982. https://doi.org/10.1051/jp4:2006134149

46. Chernai, A.V., Sobolev, V.V., Chernai, V.A., Ilyushin, M.A., \& Dlugashek, A. (2003). Laser ignition of explosive compositions based on di-(3-hydrazino-4-amino-1,2,3-triazole)-copper(II) perchlorate. Combustion, Explosion and Shock Waves, 39(3), 335-339. https://oi.org/10.1023/A:1023852505414

47. Pivnyak, G., Dychkovskyi, R., Bobyliov, O., Cabana, C.E., \& Smoliński, A. (2018). Mathematical and Geomechanical Model in Physical and Chemical Processes of Underground Coal Gasification. Solid State Phenomena, (277), 1-16. doi: https://doi.org/10.4028/www.scientific.net/SSP.277.1

48. Golovchenko, A. (2018). Automated Monitoring of Physical Processes of Formation of Burden Material Surface and Gas Flow in Blast Furnace. Solid State Phenomena, (277), 54-65. http://dx.doi.org/10.4028/www.scientific.net/SSP.277.54 
49. Malanchuk, Ye., Korniienko, V., Moshynskyi, V., Soroka, V., Khrystyuk, A., \& Malanchuk, Z. (2019). Regularities of hydromechanical amber extraction from sandy deposits. Mining of Mineral Deposits, 13(1), 49-57. https://doi.org/10.33271/mining13.01.049

50. Cherniaiev, O.V. (2017). Systematization of the hard rock non-metallic mineral deposits for improvement of their mining technologies. Naukovyi Visnyk Natsionalnoho Hirnychoho Universytetu, (5), 11-17

51. Falshtynskyi, V., Dychkovskyi, R., Saik, P., \& Lozynskyi, V. (2014). Some aspects of technological processes control of an in-situ gasifier during coal seam gasification. Progressive Technologies of Coal, Coalbed Methane, and Ores Mining, 109-112. https://doi.org/10.1201/b17547-20

52. Malanchuk, Z.R. (2019). Substantiating parameters of zeolite-smectite puff-stone washout and migration within an extraction chamber. Naukovyi Visnyk Natsionalnoho Hirnychoho Universytetu, (6), Accepted paper / Preprint.

53. Kuz'menko, O., Petlyovanyy, M., \& Stupnik, M. (2013). The influence of fine particles of binding materials on the strength properties of hardening backfill. Annual Scientific-Technical Collection - Mining of Mineral Deposits 2013, 45-48. https://doi.org/10.1201/b16354-10

54. Bondarenko, V.I., Kharin, Ye.N., Antoshchenko, N.I., \& Gasyuk, R.L. (2013). Basic scientific positions of forecast of the dynamics of methane release when mining the gas bearing coal seams. Naukovyi Visnyk Natsionalnoho Hirnychoho Universytetu, (5), 24-30.

55. Law, B.E., Ulmishek, G.F., Clayton, J.L., Kabyshev, B.P., Pashova, N.T., \& Krivosheya, V.A. (1998). Basin-centered gas evaluated in Dnieper-Donets basin, Donbas foldbelt, Ukraine. Oil and Gas Journal, 96(47), 74-78.

56. Pivnyak, G., Beshta, A., \& Balakhontsev, A. (2010). Efficiency of water supply regulation principles. New Techniques and Technologies in Mining, 1-7. https://doi.org/10.1201/b11329-2 